\title{
INTRODUCTION
}

\section{A SYNTHESIS OF CURRENT UNDERSTANDING OF THE STRUCTURAL EVOLUTION OF NORTH AFRICA}

\author{
G. Badalini $^{+*}$, J. Redfern* and I. D. Carr*
}

$\mathrm{T}$ HE AIM OF this introduction is to highlight the key tectonic events which have had significance in terms of the petroleum geology of the North African region at a basinal scale. We attempt briefly to summarise the geodynamic evolution of the ancient North African palaeocontinent, and to review the major orogenic events which deformed it during its migration from high southern latitudes in the Early Palaeozoic to its present-day position. These include the major Hercynian and Alpine orogenies and the Mesozoic extensional phase, as well as a series of "minor" though still significant tectonic events which reactivated north, NE, NW and ENE-striking structures inherited from the Pan-African Orogeny (Figs. 1,2 and 3 ).

North Africa comprises over 20 Palaeozoic basins many of which are world-class petroleum provinces (Fig. 1). The petroleum geology of North Africa has been controlled to a large degree by the structural evolution of these basins. Large-scale plate tectonic controls provided the main driving force for regional subsidence and inversion, and consequently for basin formation and evolution, sediment supply and distribution, and trap formation and style. The tectonic evolution of these sedimentary basins has influenced reservoir distribution and quality, the timing and state of source rock maturity, oil migration and preservation, and the distribution and types of traps which are present. A knowledge of the structural development of the region is fundamental to a better understanding of the relative timing of hydrocarbon generation and trap formation. More details on the structural history and petroleum systems of North Africa can be found in recent publications by Boote et al. (1998), Guiraud (1998), and MacGregor and Moody (1998).

\section{Post Pan-African and Pre-Hercynian}

The collision of a number of micro-continents during the Pan-African Orogeny resulted in the formation of a large, stable cratonic block that formed the continental margin of Gondwana and Tethys. The Precambrian basement and underlying structural lineations exerted a significant control on the subsequent Post Pan-African and Pre-Hercynian history of North Africa, which was characterized by extension, transpression and transtension together with intraplate processes. During the Cambrian, North Africa and Arabia underwent extension and intracratonic subsidence that resulted in the deposition of sediments in basins across Morocco, Algeria, Libya, Oman and Saudi Arabia. An Infra-Cambrian extensional phase is recognised, and this was followed by local transpressional and transtensional reactivation.

The deposition and present-day distribution of the Late Ordovician reservoir intervals and Early Silurian source rocks (the Tannezuft Shales) are strongly influenced by CambroOrdovician tectonism. In Libya and Algeria, Lüning et al. (2001) have demonstrated that

*North Africa Research Group, Geology (BMS), Oxford Brookes University, Headington, Oxford OX3 OBP.

+email:gbadalini@brookes.ac.uk 
the deposition of basal Silurian, organic-rich "hot shales" is restricted to palaeotopographic depressions.

The Ordovician drifting of Baltica and Avalonia from Gondwana was completed during the Silurian, with the two continents being accreted to Laurentia (Stampfli, 1996). This resulted in deformation, uplift, and local erosion (Aliev et al., 1971; Boote et al., 1998). A regionally significant unconformity can be recognised in the Late Silurian, followed by a series of progradational siliciclastics which form important reservoir units.

\section{Devonian}

By the Middle to Late Devonian, initial collision of Laurussia and Gondwana resulted in further modification of pre-existing structures (Boote et al., 1998). In western Morocco, extension / transtension and crustal thinning at this time created a series of turbiditic pullapart basins (Piqué et al., 1993).

\section{Carboniferous}

Pre-Hercynian intra-Carboniferous deformation in central North Africa has been identified within the Murzuq Basin but not, as yet, in the Algerian basins (Lüning, pers. comm.). Glacio-eustatic sea-level changes became more important during the Early Carboniferous (Ziegler, 1989), yet many major intra-Early Carboniferous sequence boundaries - evident, for instance, on the North American craton and on the Moscow Platform - cannot be correlated with each other. This suggests that they are not of global eustatic origin but are more probably related to intraplate deformation (Ziegler, 1989).

\section{Hercynian Orogeny}

The Hercynian Orogeny represents an intense period of uplift and erosion caused by the closure of the Proto-Tethyan Ocean and the Late Carboniferous collision between Gondwana and Laurussia. The intensity of deformation decreases from west to east, with folding, thrusting and strike-slip faults in NW Africa, folds and faulted folds in central north Africa, and gentle folds, disconformities and low-angle unconformities in central east Africa. The present-day maturity levels of the main Palaeozoic hydrocarbon source rocks decrease eastwards across North Africa, parallel to a decrease in the intensity of the Hercynian deformation (MacGregor, 1996).

The Hercynian Orogeny exerted significant control on hydrocarbon maturity, charge and trap configuration in North Africa. Pre-Hercynian structures were modified by Hercynian uplift and erosion, destroying many potential hydrocarbon traps for example in the Reggane and Tindouf Basins of Algeria. Remaining prospectivity often relies on assessing the potential for secondary migration and trap development. Effective Pre-Hercynian traps still exist in areas less affected by inversion. The Hercynian tectonic activity also formed broad regional arches, which acted as the foci for hydrocarbon migration from huge areas, resulting in a number of super-giant oil- and gasfields, such as Hassi Messaoud in Algeria. These structures were sufficiently large to preserve their integrity through two subsequent phases of uplift (Boote et al., 1998).

\section{Permian - Jurassic}

The initial phase of the post-Hercynian break-up of the Pangaea supercontinent spanned Late Permian to Middle Jurassic times, and culminated in the development of a new divergent/transform plate boundary between Gondwana and Laurussia (Ziegler, 1988; Lambiase, 1989; Stampfli et al., 1991; Guiraud and Bellion, 1996). Repeated phases of 


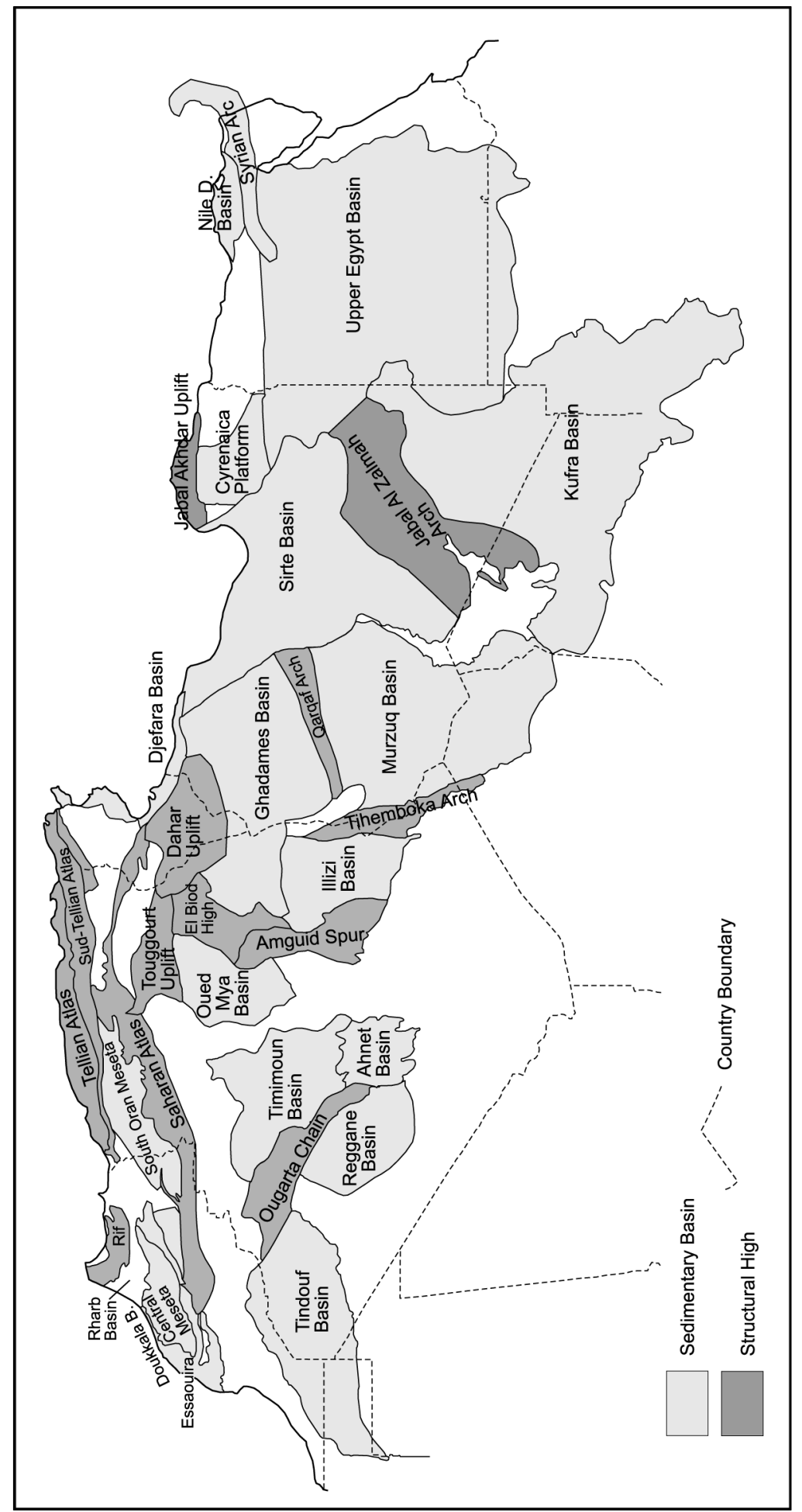

过 
rifting and inversion have affected the North African margin from the Permian to the present day. According to Guiraud (1998), rifting propagated westwards during the Permian and Triassic from the NE Arabian margin to Morocco. The Neotethys Ocean was formed in the Late Permian between Gondwana (North Africa) and the Cimmerian continental blocks, which thereafter moved rapidly northward (Stampfli, 1996). During the Late Permian to Late Triassic, Gondwana drifted northwards as an integral part of Pangaea (Schandelmeier and Reynolds, 1997). The Cimmerian continents, which had started to rift away from the NE margin of Gondwana, accelerated their separation from Gondwana during the Triassic, the Neotethys Ocean thus growing at the expense of Palaeotethys (Sengör et al., 1988). The opening of the Neotethys and the inception of the Gondwana rifts introduced a fundamental plate reorganization that was associated with the Mesozoic break-up of Pangaea (Dewey, 1988; Ziegler, 1989). Rifting continued into the Triassic/Early Jurassic associated with the break-up of Gondwana, and rifts developed into broad sag basins to the west covering Algeria, Tunisia and Libya.

\section{Early Cretaceous}

Within many basins, the Jurassic-Cretaceous transition is marked by discontinuities (hiatuses and unconformities) in the stratigraphic series (Fourcade et al., 1996). This may be associated with the sharp drop in sea level in the Late Jurassic (late Tithonian, Fig. 3), but it may also be related to tectonic events (Donze et al., 1974; Guiraud, 1998). A latest Jurassic tectonic event (the "Cimmerian event": Guiraud, 1998 and references therein) is recognized in Israel and Sinai, the Tellian Atlas, the Saharan Atlas, Morocco, the Babors, the High Atlas and around the Horn of Africa, and corresponds to the distal effects of tectonic activity (including thrusting) which occurred in southern Europe.

The Early Cretaceous opening of the Atlantic was accompanied by deformation within the African Plate, re-activating pre-existing zones of crustal weakness corresponding to the Pan-African fold belts. A phase of rifting occurred along the northern African-Arabian margin and within the intraplate domain during Neocomian to Early Aptian times (Fig. 3) (Guiraud and Maurin, 1992). Numerous rift basins were generated, and some earlier rifts were reactivated. Along the Egyptian-Libyan margin, several east-west to ENE-WSW trending half-grabens underwent strong subsidence during Neocomian-Barremian times. East-west rifting is also identified in Tunisia, where subsidence occurred along the Saharan Atlas-Aures Troughs (Guiraud, 1998) and the Riffian-Tellian Troughs. A second phase of rifting or subsidence occurred during the Middle-Late Aptian and the Early Albian, as evidenced by the presence of an unconformity within many basins (Guiraud and Maurin, 1991, 1992).

\section{Austrian Phase}

The Aptian also recorded an approximately north-south compressional event corresponding to the Austrian phase described in the European Alps (Guiraud et al., 1987). This event can be considered as a precursor to the Alpine Orogeny sensu stricto, and is recorded by a regionally important intra-Aptian unconformity evident in numerous African basins as well as in the Brazilian marginal basins (Chang et al., 1992). It inverted Early Cretaceous rift systems and reactivated older structures as far south as Central Africa (Maurin and Guiraud, 1993). In North Africa its effects were largely confined to the Atlas area and adjoining basins. Thrusting and nappe formation occurred in the northern Atlas (Tellian Basin), passing into milder inversion in the northern Pelagian Basin (Bishop, 1975; Morgan et al., 1998) with additional minor effects in the Ghadames-Triassic Basins (MacGregor and Moody, 1998). This orogenic phase resulted in uplift and deformation, with tilting of structures and associated gas flushing. 


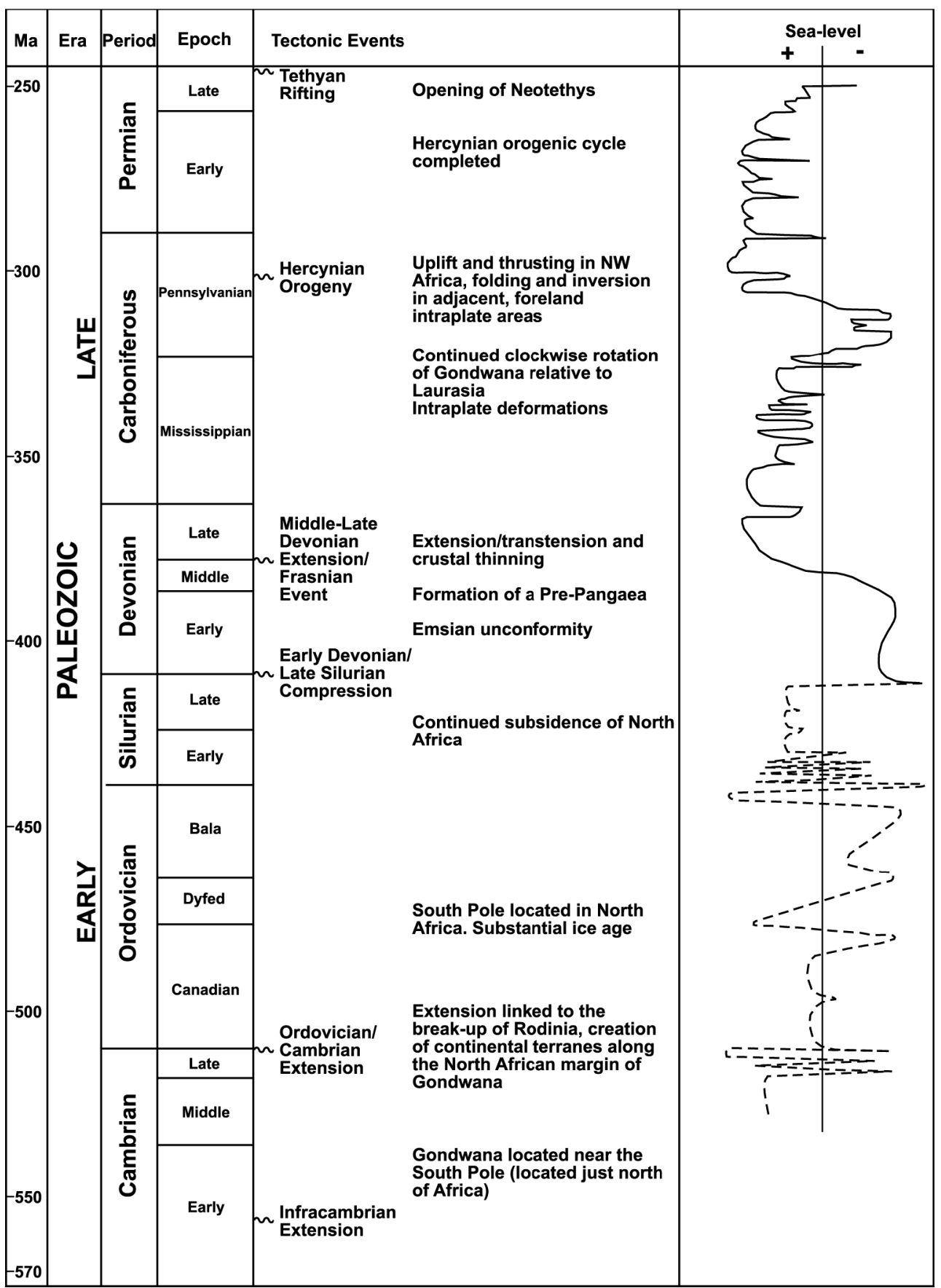

Fig. 2. Stratigraphic time scale, tectono-sedimentary events and chronology of generalized Palaeozoic sea-level fluctuations. Modified from Schandelmeier and Reynolds, 1997. 


\section{Late Cretaceous}

The Late Cretaceous was characterised by the Senonian (Turonian/Coniacian and the more intense late Santonian) compressional event, corresponding to the first stage of the collision between the African-Arabian and Eurasian Plates, and of the closure of the Neotethys Ocean. Folding and inversion of many basins was recorded along the AfricanArabian Tethyan margin (Guiraud et al., 1987, 1992). Rifting recommenced in parts of the northern African-Arabian margin in the early Campanian and continued to the late Maastrichtian or the Paleocene (Guiraud, 1998).

\section{Tertiary / Alpine Orogeny}

The Cretaceous-Tertiary boundary often exhibits unconformities, suggesting the influence of a tectonic event. Along the NE African-Levant margin, a latest Maastrichtian compressional event is recorded, continuing into the early Paleocene. Major thrusting took place in the Palmyrides (Salel and Séguret, 1994) and the Syrian Arc fold-belt developed from Lebanon to Cyrenaica (Guiraud, 1998). Some deformation also occurred along the Maghrebian Alpine fold belts, with local thrusting in the Moroccan High Atlas.

\section{Alpine Orogeny}

The Alpine Orogeny sensu stricto in North Africa started in the Late Cretaceous. Many of the Late Triassic-Early Jurassic grabens were inverted. The Atlas Mountains in Morocco (Brede et al., 1992; Lowell, 1995; Beauchamp et al., 1996, 1999; Bernini et al. 1999), western Algeria and Tunisia (Mickus and Jallouli, 1999), the Syrian Arc Fold Belt in NEEgypt (e.g. Lüning et al., 1999) and NW Arabia (e.g. Cohen et al., 1990; Chaimov et al., 1992), the Cyrenaica Platform in NE Libya (Röhlich, 1991) and parts of the Murzuq Basin in SW Libya were all affected.

During the Late Cretaceous to Paleocene Early Alpine orogenic cycle, progressive closure of oceanic domains in the western and central Mediterranean area, followed by the full-scale collision of Africa-Arabia and Europe, was accompanied by important intra-plate compressional deformation both in Europe and in North Africa (Ziegler, 1992). The AfricaArabia convergence with Europe occurred in a rotational counter-clockwise mode, controlling the main and late phases of the Alpine Orogeny (Savostin et al., 1986; Dercourt et al., 1986).

\section{Pyrenean-Atlasic Event}

The Middle Eocene represents a period of major plate reorganization (Besse and Courtillot, 1991). During Lutetian times, the Alpine orogeny caused crustal shortening and inversion of sedimentary basins in NE Africa and on the Arabian platform (Schandelmeier and Reynolds, 1997). This compressional event is related to a major stage in the collision between the African and European Plates, known as the end Lutetian Pyrenean or PyreneanAtlasic event (ca. $40 \mathrm{Ma}$ ). Many basins were tilted and uplifted, with spillage and remigration of hydrocarbons and hydrodynamic flushing from pre-existing structures (Boote et al., 1998) — and the subsequent loss of huge volumes of hydrocarbons. An understanding of the timing and nature of this Tertiary inversion is crucial to the prospectivity of many North African basins.

The Pyrenean-Atlas phase is very important in the Atlas and Aures and also affects the Tellian Chain (Guiraud et al., 1987), affecting the Saharan platform with less intensity. Its effects are also recorded in the Triassic Basin of Algeria (Boudjema, 1987), in northern Libya, the Atlas Basins of Morocco and Algeria, and the Benue Trough in West Africa (Guiraud et al., 1987; Bellion and Guiraud, 1988).

During late Eocene-Recent time, other compressional events occurred (Guiraud and Bellion, 1996). Thrusting (and metamorphism) characterize the Aquitanian-Burdigalian 


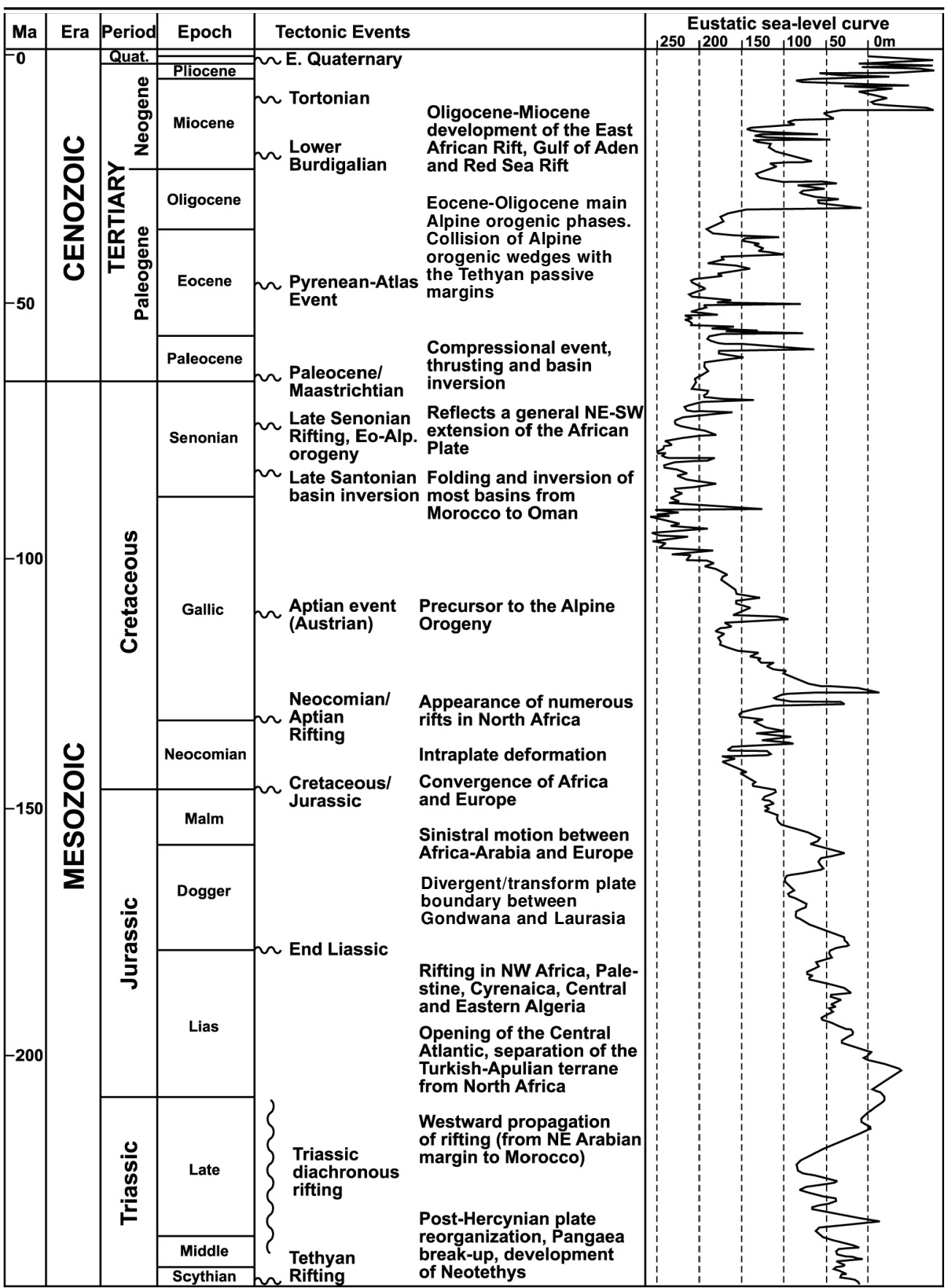

Fig. 3. Stratigraphic time scale, tectono-sedimentary events and chronology of generalized Mesozoic -Cenozoic sea-level fluctuations. Modified from Schandelmeier and Reynolds, 1997. 
boundary and probably resulted in the end of Oligocene-early Miocene rifting. Another important event, responsible for dextral, transpressive deformation along the NE African and northern Arabian plate margins, took place during the Tortonian. Finally, an early Pleistocene event occurred in Africa-Arabia, characterized by NW-SE to north-south shortening, which is documented along the northern margin.

\section{AKNOWLEDGEMENTS}

The authors are grateful for technical input and advice from S. Lüning, and financial support from the sponsoring companies Amerada Hess, Anadarko, Burlington Resources, BG Group and Phillips Petroleum.

\section{REFERENCES}

ALIEV, M., AÏT LASOUSSINE, N., AVROV, V., ALEKSINE, G., BAROULINE, G., LAKOVLEV, B., KORJ, M., KOUVYKINE, V., MAZANOV, V., MEDVEDEV, E., MKRTCHIANE, O., MOUSTAFINOV, R., ORIEV, L., OROUDJEVA, D., OULMI, M. and SAÏD, A., 1971. Geological structure and estimation of oil and gas in the Sahara in Algeria. Altamira-Rotopress, S.A., 265p.

BEAUCHAMP, W., BARAZANGI, M., DEMNATI, A. and EL ALJI, M., 1996. Intracontinental rifting and inversion: Missour Basin and Atlas Mountains, Morocco. AAPG Bull., 80, 1459-1482.

BEAUCHAMP, W., ALLMENDINGER, R. W., BARAZANGI, M., DEMNATI, A., EL ALJI, M. and DAHMANI, M., 1999. Inversion tectonics and the evolution of the High Atlas Mountains, Morocco, based on a geological-geophysical transect. Tectonics, 18, 163-184.

BELLION, Y. and GUIRAUD, R., 1988. Deformations d'origine compressive d'age intra éocène à l'Ouest de l'Adrar des Iforas (Mali). C. R. Acad. Sci., Paris, 307, 529-532.

BERNINI, M., BOCCALETTI, M., GELATI, R., MORATTI, G., PAPANI, G. and EL MOKHTARI, J., 1999. Tectonics and sedimentation in the Taza-Guercif Basin, northern Morocco: Implications for the Neogene evolution of the Rif - Middle Atlas Orogenic System. Journ. Petrol. Geol., 22, 115-128.

BESSE, J.C. and COURTILLOT, V., 1991. Revised and synthetic apparent polar wander paths of the African, Eurasian and Indian Plate, and the true polar wander since 200Ma. Journ. Geophysical Research, 96, 4029-4050.

BISHOP, W.F., 1975. Geology of Tunisia and adjacent parts of Algeria and Libya. AAPG Bull., 59, 413450.

BOOTE, D.R., CLARK-LOWES, D.D. and TRAUT, M.W., 1998. Palaeozoic petroleum systems of North Africa. In: MacGregor, D.S., Moody, R.T.J. and Clark-Lowes, D.D. (Eds.), Petroleum Geology of North Africa. Geol. Soc. Spec. Publ., 132, 7-68.

BOUDJEMA, A., 1987. Evolution structurale du bassin pétrolier "Triassique" du Sahara Nord Oriental (Algérie). Thèse de l'Université de Paris Sud, 290p.

BREDE, R., HAUPTMANN, M. and HERBIG, H.G., 1992. Plate tectonics and intracratonic mountain ranges in Morocco - the Mesozoic-Cenozoic development of the Central High Atlas and Middle Atlas. Geol. Rundsch., 81, 127-141.

CHAIMOV, T.A., BARAZANGI, M,. AL-SAAD, D., SAWAF, T. and GEBRAN A., 1992. Mesozoic and Cenozoic deformation inferred from seismic stratigraphy in the southwestern intracontinental Palmyride fold-thrust belt, Syria. Geol. Soc. Am. Bull., 104, 704-715.

CHANG, H.K., KOWSMANN, R.O., FIGUEIREDO, A.M.F. and BENDER, A.A., 1992. Tectonic and stratigraphy of the east Brazil rift system: an overview. In: Ziegler, P.A. (Ed.), Geodynamics of rifting, Volume II. Case history studies on rifts: North and South America and Africa. Tectonophysics, 213, 97138.

COHEN, Z., KAPTSAN, V. and FLEXER, A., 1990. The tectonic mosaic of the southern Levant: Implications for hydrocarbon prospects. Journ. Petrol. Geology, 13, 437-462.

DERCOURT et al., 1986. Geological evolution of the Tethys belt from the Atlantic to the Pamirs since the Lias. In: Aubouin, J., Le Pichon, X., Monin, A.S. (Eds.), Evolution of the Tethys, 241-315.

DEWEY, J.F., 1988. Lithospheric stress, deformation, and tectonic cycles: the disruption of Pangaea and the closure of Tethys. In: Audley-Charles, M.G. and Hallam, A. (Eds.), Gondwana and Tethys. Geol. Soc. Spec. Publ., 37, 23-40. 
DONZE, P., GUIRAUD, R. and LE HÉGARAT, G., 1974. A propos du passage Jurassique-Crétacé en domain mésogéen: revision des principales coupes du Sud-Ouest constantinois. C. R. Acad. Sci., Paris, 278 (13), 1607-1700.

FOURCADE, E., AZEMA, J., BASSOUllet, J.P., CECCA, F. and DERCOURT, J., 1996. Palaeogeography and palaeoenvironment of the Tethyan realm during the Jurassic break-up of Pangaea. In: Nairn, A.E.M., Ricou, L.E., Dercourt, J. and Wrielynck, B. (Eds.), The Ocean basins and margins, Vol. 8, The Tethys Ocean. Plenum Press, pp. 190-214.

GUIRAUD, R., 1998. Mesozoic rifting and basin inversion along the northern African Tethyan margin: an overview. In: MacGregor, D.S., Moody, R.T.J. and Clark-Lowes, D.D. (Eds.), Petroleum Geology of North Africa. Geol. Soc. Spec. Publ., 132, 217-229.

GUIRAUD, R., BELLION, Y, BENKHELIL, J. and MOREAU, C., 1987. Post-Hercynian tectonic in Northern and Western Africa. Geological Journal, 22, 433-466.

GUIRAUD, R. and BELLION, Y., 1996. Late Carboniferous to Recent geodynamic evolution of the West Gondwanian cratonic Tethyan margins. In: Nairn, A.E.M., Dercourt, J. and Wrielynck, B. (Eds.), The ocean basin and margins, Vol. 8, The Tethys Ocean. Plenum Press, pp. 101-124.

GUIRAUD, R., BINKS, R.M., FAIRHEAD, J.D. and WILSON, M., 1992. Chronology and geodynamic setting of Cretaceous-Cenozoic rifting in West and Central Africa. Tectonophysics, 213, 227-234.

GUIRAUD, R. and MAURIN, J.C., 1991. Le rifting en Afrique au Crétacé inférieur: synthèse structurale, mise en évidence de deux étapes dans la genèse d'un accident majeur à l'échelle de la plaque africaine. C. R. Acad. Sci., Paris, 293, 779-782.

GUIRAUD, R. and MAURIN, J.C., 1992. Early Cretaceous rifts of Western and Central Africa: an overview. Tectonophysics, 213, 153-168.

LAMBIASE, J.J., 1989. The framework of African rifting during the Phanerozoic. Journ. African Earth Sciences, 8, 183-190.

LOWELL, J.D., 1995. Mechanics of basin inversion from worldwide examples. In: Buchanan, J.G., Buchanan, P. G. (Eds), Basin inversion. Geol. Soc. Spec. Publ., 88, 39-57.

LÜNING, S., CRAIG, J., FITCHES, B. MAYOUF, J., BUSREWIL, A., EL DIEB, M., GAMMUDI, A., LOYDELL, D. and McILROY, D., 1999. Re-evaluation of the petroleum potential of the Kufra Basin (SE Libya, NE Chad): does the source rock barrier fall? Marine and Petroleum Geology, 16, 693-718.

LÜNING, S., CRAIG, J., LOYDELL, D. K., STORCH, P., and FITCHES, B., 2001. Lower Silurian "hot shales" in North Africa and Arabia; regional distribution and depositional model. Earth-Science Reviews, 49, 121-200.

MacGREGOR, D.S., 1996. The hydrocarbon systems of North Africa. Marine and Petroleum Geology, 13, 329-340.

MacGREGOR, D.S. and MOODY, R.T.J., 1998. Mesozoic and Cenozoic petroleum systems of North Africa. In: MacGregor, D.S., Moody, R.T.J., Clark-Lowes, D.D. (Eds.), Petroleum Geology of North Africa. Geol. Soc. Spec. Publ., 132, 201-216.

MAURIN, J.C. and GUIRAUD, R., 1993. Basement control in the development of the Early Cretaceous West and Central African rift systems. Tectonophysics, 228, 81-95.

MICKUS, K. and JALLOULI, C., 1999. Crustal structure beneath the Tell and Atlas Mountains (Algeria and Tunisia) through the analysis of gravity data. Tectonophysics, 314, 373-385.

MORGAN, M.A., GROCOTT, J. and MOODY, R.T., 1998. The structural evolution of the ZaghouanRessa Structural belt, northern Tunisia. In: MacGregor, D.S., Moody, R.T.J. and Clark-Lowes, D.D. (Eds.), Petroleum Geology of North Africa. Geol. Soc. Spec. Publ., 132, 405-422.

PIQUÉ, A.B., G., BOULLIN, J-P., CHALOUAN, A., and HOEPFFNER, C., 1993. Southern margin of the Variscan belt: the north-western Gondwana mobile zone (eastern Morocco and Northern Algeria). Geol. Rundsch., 82, 432-439.

RÖHLICH, P., 1991. Tectonic development of Jabal al Akhdar. In: Salem, M.J., Busrewil, M.T. (Eds), The Geology of Libya. Academic Press, 3, 923-931.

SALEL, J.F. and SÉGURET, M., 1994. Late Cretaceous to Paleogene thin-skinned tectonics of the Palmyrides belt (Syria). Tectonophysics, 234, 265-290.

SAVOSTIN, L.A., SIBUET, J.C., ZONENSHAIN, L.P. LEPICHON, X., and ROULET, M.J., 1986. Kinematic evolution of the Tethys belt from the Atlantic to the Pamirs since the Triassic. Tectonophysics, 123, 1-35.

SCHANDELMEIER, H., and REYNOLDS, P.O., 1997. Palaeogeographic-palaeotectonic atlas of the North-Eastern Africa, Arabia, and adjacent areas. Balkema, Rotterdam, 160p.

SENGÖR, A.M.C., ALTMER, D., CIN, A., USTAÖMER, T. and HSÜ, K.J., 1988. Origin and assembly of the Tethyside orogenic collage at the expense of Gondwana Land. In: Audley-Charles, M.G. and 
Hallam, A. (Eds.), Gondwana and Tethys. Geol. Soc. Spec. Publ. 37, 119-181.

STAMPFLI, G., 1996. The intra-Alpine terrain: a Palaeotethyan remnant in the Alpine Variscides. Eclogae Geologicae Helveticae, 89, 13-42.

STAMPFLI, G., MARCOUX, J. and BAUD, A., 1991. Tethyan margin in space and time. Palaeogeography, Palaeoclimatology, Palaeoecology, 87, 373-409.

ZIEGLER, P.A., 1988. Evolution of the Arctic-North Atlantic and Western Tethys. AAPG Memoir 43, $198 \mathrm{p}$.

ZIEGLER, P.A., 1989. Evolution of Laurassia. Kluwer Academic Publishers, Dordrecht, 102p.

ZIEGLER, P.A., 1992. Plate tectonics, plate moving mechanisms and rifting. Tectonophysics, 215, 9-34. 